\title{
A STUDY OF THE LOCALISATION OF A PROTEIN ANTIGEN IN THE CHICKEN SPLEEN AND ITS RELATION TO THE FORMATION OF GERMINAL CENTRES
}

\author{
R. G. White, Valentine I. French and J. M. Stark \\ Department of Bacteriology and Immunology, University of Glasgow \\ Plates II-VII
}

ONE of the first applications of the fluorescent antibody method was the in-vivo tracing of injected polysaccharide and protein antigens by Coons and his colleagues (Coons et al., 1942; Coons and Kaplan, 1950; Coons, Leduc and Kaplan, 1951). Insofar as foreign proteins were used, these were found rapidly to gain access to cells of the reticulo-endothelial system, from which they disappeared quickly, so that ovalbumin and human serum albumin were no longer detectable after 2 days. A further immunofluorescence study (White, 1963) of the fate of human serum albumin (HSA) injected intravenously into the chicken revealed that this immunogen localised to certain cells, designated "dendritic cells, probably a type of macrophage", in the germinal centres within the white pulp of the spleen, and persisted at these sites for at least $2 \mathrm{wk}$. Subsequently Ada, Nossal and Pye (1964), Nossal, Ada and Austin (1964) and McDevitt et al. (1966) reported the use of radio-iodine-labelled antigen and its in-vivo localisation in the rat and mouse by autoradiography. The present communication deals with the further analysis, by use of the fluorescent antibody and autoradiography methods, of the cellular events that follow the intravenous injection of immunogens into the chicken.

\section{MATERIALS AND METHODS \\ Animals and antigen}

Chickens. White Leghorn cockerels aged 6-14 wk were used for most of the experiments. The experiments in which birds were rendered specifically tolerant to HSA were done with a variety of hybrid birds of both sexes, including Rhode Island Red $\times$ White Leghorns, Light Sussex $\times$ White Leghorns and the commercial hybrids Dekalb and Thornber 606 .

Antigen. Crystalline human serum albumin (HSA, " purified ", Behringwerke AG) was injected in $0 \cdot 15 \mathrm{M}-\mathrm{NaCl}$ without adjuvants.

Phosphate-buffered saline. Phosphate-buffered saline (PBS) was prepared by the addition of $\mathrm{NaCl}$ to $0.01 \mathrm{M}$ phosphate buffer $\left(\mathrm{KH}_{2} \mathrm{PO}_{4} / \mathrm{Na}_{2} \mathrm{HPO}_{4}\right) p \mathrm{H} 7 \cdot 2$, to give a final concentration of $0 \cdot 15 \mathrm{M}-\mathrm{NaCl}$.

\section{Production of fuorescein isothiocyanate-labelled antisera}

Antiserum to human serum albumin. Rabbits were given an initial injection of $0.5 \mathrm{ml}$ of water-in-oil emulsion containing $5 \mathrm{mg}$ HSA and $1 \mathrm{mg}$ of heat-killed human type Mycobacterium tuberculosis (complete Freund-type adjuvant), divided and injected in equal amounts into the subcutaneous tissue of the inner thigh of both legs. A secondary injection

Received 8 May 1969; accepted 1 June 1969.

* Departmental publication no. 6927. 
of $5 \mathrm{mg}$ HSA adsorbed to a colloidal suspension of $1.5 \mathrm{mg}$ of aluminium phosphate, volume $0.5 \mathrm{ml}$, was given partly subcutaneously and partly intravenously 4 wk later. Blood was obtained 7-14 days after and the level of antibody estimated by a quantitative precipitation test (Kabat and Mayer, 1961). Sera showing high antibody levels were precipitated at a concentration of 33 per cent. saturated ammonium sulphate. The globulin fraction thus obtained, after resuspension and dialysis against $0 \cdot 15 \mathrm{M}-\mathrm{NaCl}$ was conjugated with fluorescein isothiocyanate (G. T. Gurr, Ltd) by use of 3-5 mg fluorescein per $100 \mathrm{mg}$ protein. Unreacted fluorescein was removed by passing the conjugate through a column of $6 \mathrm{~g}$ of G-25 Sephadex equilibrated with PBS. The remaining non-specific fluorescence was removed in one of two ways. Either the resultant conjugate, after passage through G-25 Sephadex equilibrated with PBS, was passed through a column of DEAE cellulose equilibrated with PBS, and the first peak after the passage of one column volume was collected, or the supernatant from the second of two absorption procedures with acetone-lyophilised mouse liver powder $(100 \mathrm{mg}$ per $\mathrm{ml}$ ) prepared by the method of Coons and Kaplan was used.

Antiserum to chicken $7 S$ immunoglobulin. High-titre rabbit anti-chicken-globulin was prepared by immunisation of rabbits with a fraction of chicken globulin obtained by precipitation with 20 per cent. sodium sulphate at room temperature by Dr J. H. Humphrey. Conjugation with fluorescein isothiocyanate was carried out as detailed above. Immunoelectrophoretic analysis of this antiserum demonstrated a strong precipitin arc with chicken $7 \mathrm{~S}$ immunoglobulin, though antibodies against $19 \mathrm{~S}$ immunoglobulin were also present in small amounts.

\section{Preparation and immunofluorescence staining of chick tissues}

Chickens were killed with an overdose of intravenous sodium pentobarbitone. Spleens, cut into two or three pieces, were lodged on the walls of thin-walled glass tubes, which were then sealed with a rubber bung and rapidly frozen by immersion in a freezing mixture at $-70^{\circ} \mathrm{C}$. Sections $4 \mu \mathrm{m}$ thick were cut in a cryostat at $-20^{\circ} \mathrm{C}$, placed on glass microscope slides, melted and dried in a stream of warm air, and fixed in absolute methanol at $20^{\circ}-24^{\circ} \mathrm{C}$ for $15 \mathrm{~min}$. After being rapidly dried in a current of warm air the sections were stained in one of the following ways.

To demonstrate the presence of the antigen (HSA). To secure hydration of the tissue the slides were briefly dipped in PBS. Fluorescein-labelled anti-HSA was applied as a drop directly over the section, which was left in a moist chamber at room temperature for 30 min., transferred to PBS and washed with intermittent shaking for $10 \mathrm{~min}$. before mounting in PBS.

To demonstrate the presence of antibody to HSA. A solution of HSA ( $2 \mathrm{mg}$ per $\mathrm{ml}$ in $0 \cdot 15 \mathrm{M}-\mathrm{NaCl}$ ) was first applied to the spleen section, followed after a 5-min. wash in phosphatebuffered saline by fluorescein-labelled anti-HSA. This "sandwich" technique (Coons, Leduc and Connolly, 1955) will also demonstrate the presence of antigen (HSA) in the tissue as in the direct method of staining described above. However, by comparison of two adjacent sections, one stained by each method, antibody can be differentiated from antigen by its presence only in the section stained by the two layers of the "sandwich" technique.

To demonstrate the presence of chicken $7 S$ immunoglobulin. Fluorescein-labelled antichicken-7S-immunoglobulin was applied directly to the tissue for $30 \mathrm{~min}$., followed by a 10-min. wash in PBS.

Fluorescence microscopy. The tissue sections were mounted in PBS and examined microscopically with a Leitz Ortholux fluorescence microscope fitted with an Osram HBO 200 high-pressure mercury arc, oil-immersion objectives and a cardioid bi-reflecting darkground condenser. The exciter filters were BG12 $(2 \mathrm{~mm})$ and BG38 $(3 \mathrm{~mm})$. The barrier filter was Wratten gelatin no. 12 or Schott OG1.

\section{Production of specific immunological tolerance for HSA in newly hatched chickens}

Birds were given an intraperitoneal injection of $25 \mathrm{mg}$ crystalline HSA immediately after hatching, and two more injections of the same dose in the 1st wk of life. Further injections of $25 \mathrm{mg}$ were given intraperitoneally twice a week for a further $2 \mathrm{wk}$ and then continued 
once weekly until the birds were tested for tolerance after the 6th wk. The completeness of tolerance for HSA was determined by observing the elimination of 131I-HSA for a period of 8 days by whole-body counting. In tolerant birds a uniformly exponential rate of elimination was maintained (half-life 1.25 days). In control birds with the same approximate rate of initial elimination (half-life 1.25 days) the rate increased after the 4th day because of the onset of an immunological response. In this part of the curve half lives of 0.4-0.6 days were found.

Isotope labelling. Human serum albumin (HSA) was trace-labelled with radio-iodine by the direct oxidation technique of Hunter and Greenwood (1962) by the use of Chloramine T and thiosulphate-free isotope (IBS.3 iodine-131 or IMS.3 iodine-125 from the Radiochemical Centre, Amersham, England).

Different levels of activity were required for whole-body counting (not more than $7.5 \mu \mathrm{Ci}$ per $10 \mathrm{mg}$ protein dose), the Farr test (about $0.5 \mu \mathrm{Ci}$ per $\mu \mathrm{g}$ ) and autoradiography (up to $25 \mu \mathrm{Ci} \mathrm{per} \mu \mathrm{g}$ ). Previous experience had shown that 35-40 per cent. of the radioactive isotope could be attached to the protein. When high activities were required for autoradiography, the technique was modified in the manner of Ada, Nossal and Pye. For lower activities the protein was dissolved in a volume between $0.5 \mathrm{ml}$ and $2 \mathrm{ml} 0.1 \mathrm{M}$ sodium phosphate buffer at $p \mathrm{H} 7.5$ and added simultaneously with $250 \mu \mathrm{g}$ chloramine $\mathrm{T}$ in $0.25 \mathrm{ml}$ buffer to the isotope. After addition of sodium metabisulphite and potassium iodide the free iodide ions were separated from the labelled protein by passage through a 30-cm G-25 Sephadex column $1 \mathrm{~cm}$ in diameter.

\section{Antigen-binding capacity of chicken antisera to HSA: estimation of serum antibody levels by the Farr test}

Quantitative estimation of antibody as antigen-binding capacity was carried out by a modification of the method of Farr (1958) (see Campbell et al., 1964). The trace-labelled HSA was used at a concentration of $0.4 \mu \mathrm{g}$ per $\mathrm{ml}$. Tubes containing undiluted test serum and test serum diluted 1 in 5,1 in 25 and 1 in 125 in normal chicken serum, in $0.1 \mathrm{ml}$ volumes, were set up in duplicate. Subsequently, $0.5 \mathrm{ml}$ of the trace-labelled antigen solution was added to each tube. After the tubes had been kept for $2 \mathrm{hr}$ in a refrigerator at $4^{\circ} \mathrm{C}, 0.4 \mathrm{ml}$ ammonium sulphate solution (saturated at $4^{\circ} \mathrm{C}$ ) was added to each. After precipitation had taken place overnight at $4^{\circ} \mathrm{C}$, the deposits were spun in a refrigerated centrifuge $\left(4^{\circ} \mathrm{C}\right)$ at $850 \mathrm{~g}$ and washed in 40 per cent. saturated ammonium sulphate. This washing procedure was repeated once more, and the final precipitate was dissolved in $1 \mathrm{ml}$ normal saline. Four tubes containing $0.1 \mathrm{ml}$ normal chicken serum were included in the test. One pair was treated as were the other sera under test to determine the minimal precipitations of 131I-HSA in the absence of antibody. To the other pair of tubes $0.6 \mathrm{ml} 10$ per cent. trichloracetic acid (TCA) was added to determine the maximum precipitable radioactivity of 131 I-HSA. The resulting precipitate was centrifuged and washed in $1 \mathrm{ml}$ of TCA and resuspended for counting in $1 \mathrm{ml}$ saline. The washed precipitates from all tubes and the supernates from the normal chicken serum and TCA tubes were counted in a well-type sodium iodide crystal scintillation counter.

The radioactive counts of the precipitate were plotted against the serum dilution on semilog paper and the dilution of $0.1 \mathrm{ml}$ serum equivalent to 30 per cent. precipitation determined (where 100 per cent. = total TCA-precipitable protein minus the normal serum precipitate). From this the antigen-binding capacity $\left(\mathrm{ABC}_{30}\right.$ in $\mu \mathrm{g}$ per $\left.\mathrm{ml}\right)$ was calculated.

\section{Estimation of serum levels of antigen (131I-HSA) in the form of antigen-antibody complexes}

Antigen (131I-HSA) in combination with homologous antibody can be precipitated from chicken serum by 40 per cent. saturation with ammonium sulphate. This differentiates such complexes from free HSA and 131I-HSA, which are not precipitated by the same concentration of ammonium sulphate. Birds were given an intravenous injection of $10 \mathrm{mg}$ HSA previously labelled in vitro with $0.3 \mathrm{mCi}$ iodine- 131 . To $0.1 \mathrm{ml}$ duplicate samples of serum, $0.5 \mathrm{ml}$ saline and $0.4 \mathrm{ml}$ saturated ammonium sulphate were added at $4{ }^{\circ} \mathrm{C}$. The precipitate 
formed after preservation of the mixture for $18 \mathrm{hr}$ at $4^{\circ} \mathrm{C}$ was spun down in a refrigerated centrifuge at $4^{\circ} \mathrm{C}$, washed twice in 40 per cent. saturated ammonium sulphate and made up to $1 \mathrm{ml}$. To identical $0.1 \mathrm{ml}$ serum samples, $0.9 \mathrm{ml}$ saline was added. The samples were counted in a scintillation counter and the precipitable HSA counts per $0.1 \mathrm{ml}$ serum were expressed as a percentage of the total HSA counts per $0.1 \mathrm{ml}$ serum in each daily sample.

\section{Determination of the rate of elimination of antigen (131I-HSA) from injected birds by whole-body counting}

Chickens 5-6-wk old were given an intravenous injection of $10 \mathrm{mg}$ HSA trace-labelled in vitro with 5-7 $\mu \mathrm{Ci}$ of ${ }^{131} \mathrm{I}$. All birds were provided with 0.01 per cent. sodium iodide in $0.075 \mathrm{M}-\mathrm{NaCl}$ in place of drinking water for 3 days before the injection of antigen. Wholebody counts of 131I-HSA were obtained daily by the use of a plastic well-scintillation counter of sufficient size to enclose the bird (Nuclear Enterprises, Sighthill, Scotland).

Preparation of autoradiographs. White Leghorn chickens 6-10 wk old were given an intravenous injection of $40 \mu \mathrm{g}$ of 125I-HSA, which had been heavily labelled in vitro to a level of $25 \mu \mathrm{Ci}$ per $\mu \mathrm{g}$. Spleens were obtained from birds killed with an intravenous dose of pentobarbitone sodium at time-intervals from $16 \mathrm{hr}$ to 7 days after injection of antigen. They were frozen to $-70^{\circ} \mathrm{C}$ and sectioned at $-20^{\circ} \mathrm{C}$ in a cryostat at $4 \mu \mathrm{m}$ thickness. After air-drying and fixation for $15 \mathrm{~min}$. in absolute methanol at room temperature, they were dipped into Ilford Nuclear Research Emulsion K5 and exposed for 1 half-life of 125I (60 days). The slides were then developed by Microdol developer (Kodak), fixed, and stained with Leishman's stain or by the Unna-Pappenheim method with methyl green-pyronin.

Determination of half-life of chicken $7 \cdot 7 \mathrm{~S}$ immunoglobulin. The globulin used for these determinations was prepared from a pool of normal chicken sera which was precipitated at 22.5 per cent. saturation with ammonium sulphate. The serum was dialysed against PBS and trace-labelled with iodine- 131 by the method of Hunter and Greenwood. Amounts of $2 \mathrm{ml}$ were injected into one 10-wk-old and one 10-mth-old bird. Serum samples were collected 2, 4, 7, 9 and 12 days after injection. The radioactivity of convenient volumes was estimated in a well-type (sodium iodide crystal) scintillation counter. Both birds were provided during the period of observation with 0.01 per cent. potassium iodide in $0.075 \mathrm{M}-\mathrm{NaCl}$ in place of drinking water.

\section{RESULTS}

\section{The primary response in the serum of 6-10-wk-old birds to an intravenous injection of $10 \mathrm{mg}$ of human serum albumin}

The serum antibody levels of individual birds after an intravenous injection of $10 \mathrm{mg}$ of human serum albumin (HSA) are expressed in fig. 1 (individual birds) as antigen (HSA) binding capacities $\left(\mathrm{ABC}_{30}\right)$. Detectable antibody first made its appearance in the serum at 4 days after injection and increased to a maximum at 8-12 days. The maximum was followed by a sharp drop to very low levels of serum antibody at 16 days. No evidence was found in this sample of birds of a later rise in the levels of antibody, which were estimated up to 42 days after injection.

\section{Elimination of an intravenous injection of $10 \mathrm{mg}$ of ${ }^{131} \mathrm{I}-\mathrm{HSA}$}

The counts of radioactivity in blood samples obtained during the period of elimination of a $10 \mathrm{mg}$ intravenous dose of $131 \mathrm{I}-\mathrm{HSA}$ are shown in fig. 2. After an initial period of 2-3 days when the antigen was eliminated with a uniform half-life of 1.25 days, the rate of elimination abruptly increased to a half-life of $0 \cdot 3$ day. Almost all of the injected antigen was eliminated from the circulation by the 6th day after injection. 
Occurrence of antigen-antibody complexes in the circulation of chickens given injections of 131 I-HSA

Antigen (131I-HSA) present in the blood of chickens in the form of soluble complexes with homologous antibody was estimated as counts of radioactivity precipitable from serum by addition of ammonium sulphate to a final concentration of 40 per cent. (see Materials and methods). As fig. 2 shows, the percentage of 131I-HSA that is associated with complexes with antibody starts to rise on the 3 rd -4 th day and continues to increase to the 6 th day, at which time

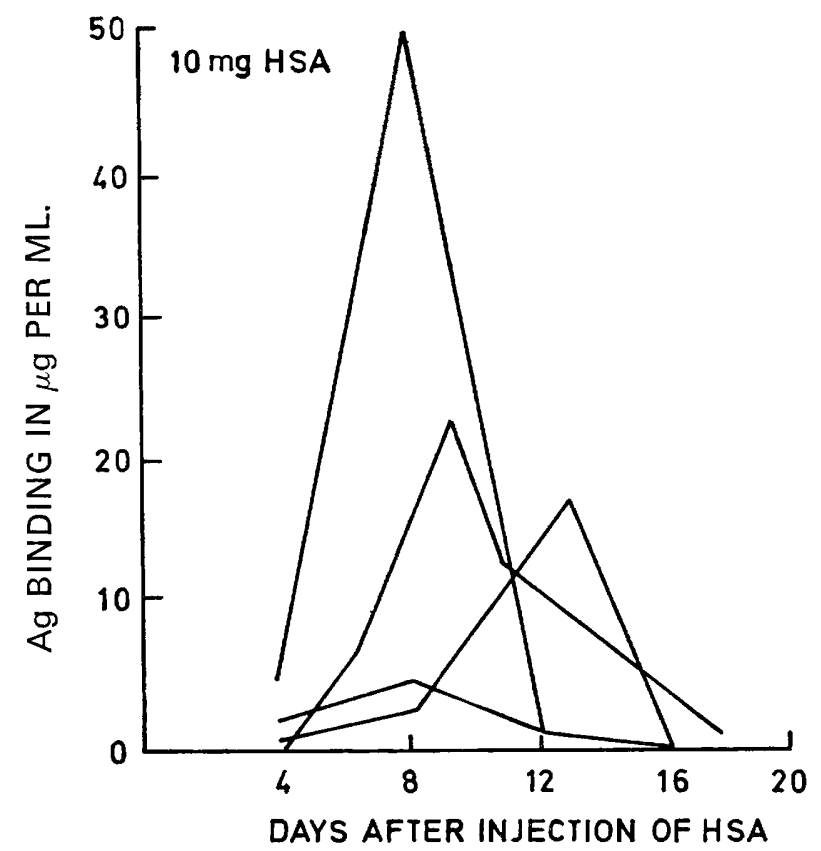

FIG. 1.-Levels of anti-HSA in the sera of four individual chickens (expressed as antigen-bindingcapacity or $\mu \mathrm{g}$ of antigen bound per $1 \mathrm{ml}$ serum at 30 per cent. binding) plotted against time in days after an intravenous injection of $10 \mathrm{mg} \mathrm{HSA}$.

estimation showed that 68 per cent. of the antigen present in a blood sample existed in the form of complexes with homologous antibody. Estimation of levels of free antibody showed that this first became detectable on day 5 and rose rapidly during days 6,7 and 8 . Antibody levels were not estimated at periods beyond 9 days, but the general experience with other experimental birds indicates that a maximum is usually attained at days 8-12.

The evolution of the cellular response in the spleen after an intravenous injection of $H S A$

Approximately 50 chickens were given an intravenous injection of $10 \mathrm{mg}$ HSA in $1 \mathrm{ml}$ of $0 \cdot 15 \mathrm{M}-\mathrm{NaCl}$. They were killed at varying time-intervals after injection. The frozen spleens were sectioned in a cryostat and examined for 
the presence of the antigen (HSA), antibody to HSA, and chicken 7.7S immunoglobulin. The pattern of immunohistological response is summarised in fig. 3 . Human serum albumin could not be detected in sections of the spleen at 7-24 hr after injection. At $24 \mathrm{hr}$ one of the spleens examined shows the presence of antigen on a few scattered cells in the white pulp only. The number of such antigen-bearing cells increases rapidly in the white pulp over the next $20 \mathrm{hr}$ as shown in table I. Similar antigen-bearing cells are never present in the red

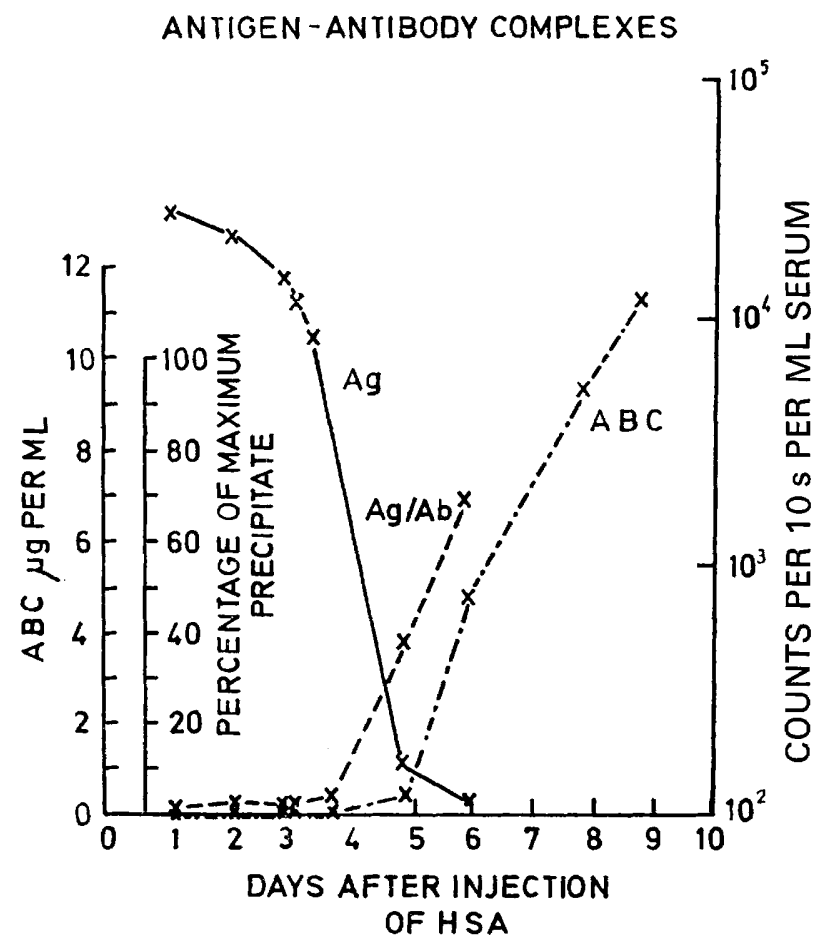

FIG. 2.-Elimination of antigen HSA (solid line Ag), rise of antibody (-..... ABC) and increase in HSA-anti-HSA complexes (- - $\mathrm{Ag} / \mathrm{Ab})$ during a 10-day period after an intravenous injection of $10 \mathrm{mg}$ HSA. Ordinates: serum antibody expressed as antigen-binding-capacity $(\mu \mathrm{g}$ of antigen bound per $1 \mathrm{ml}$ serum at 30 per cent. binding); HSA in serum expressed as counts per $10 \mathrm{~s}$ per $\mathrm{ml}$ of serum; and HSA-anti-HSA complexes in serum expressed as percentage of $131 \mathrm{I}$-counts precipitable at 40 per cent. saturation of $\left(\mathrm{NH}_{4}\right)_{2} \mathrm{SO}_{4}$.

pulp. Initially the antigen is associated with isolated cells arranged around and close to the penicillary arterioles of the white pulp (fig. 4). By the 4th day after injection, some of these cells are present within small germinal centres (fig. 5) and by the 6th day antigen-bearing cells are found only in germinal centres (fig. 6), none remaining scattered in the white pulp outside. Counts were made of fluorescent antigen-bearing cells in two frozen sections from different tissue-blocks of spleens of birds killed at 24, 32 and $44 \mathrm{hr}$ and 7 days after injection of antigen. By means of a stage micrometer, a measured area of the sections was surveyed for groups of antigen-bearing cells. Table I shows that the number of cells found within the germinal centres has increased 
between the 4th and 7 th days. The centres also increase in size from the 4th to the 7 th day (figs. 5 and 6). From the 7 th day onwards the intensity of fluorescence of the antigen-bearing cells within the germinal centres decreases, but in some spleen sections antigen is still detectable by this technique up to the 42nd day.
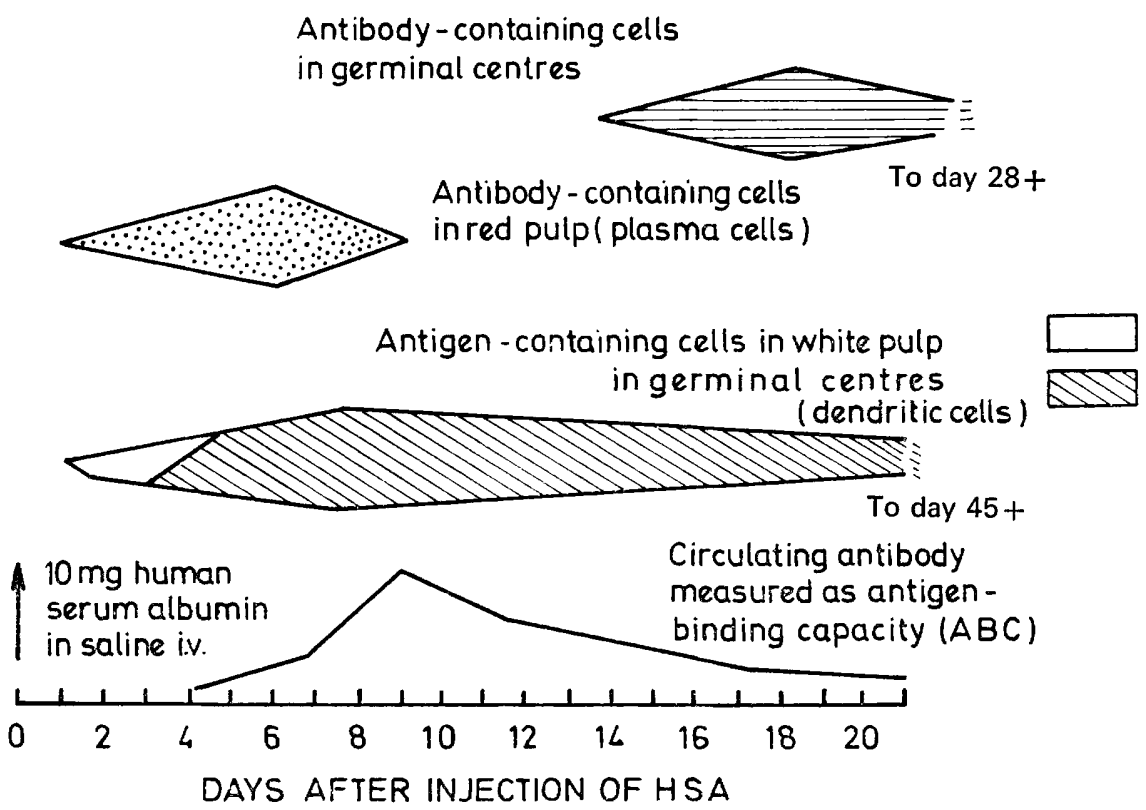

FIG. 3.-Primary response in chicken spleen to intravenous (i.v.) injection of HSA. Diagram to illustrate correlation in time of : (i) anti-HSA level (as measured by Farr technique) in serum; (ii) numbers of antigen-bearing cells in white pulp (outside germinal centres) and numbers of antigen-bearing cells in germinal centres; (iii) numbers of antibody-containing plasma cells in red pulp; (iv) numbers of late-appearing antibody-containing cells in germinal centres.

TABLE I

Location of immunofluorescent HSA-bearing cells in chicken spleen

\begin{tabular}{c|c|c|c|c}
\hline $\begin{array}{c}\text { Time after } \\
\text { injection of } \\
\text { antigen }\end{array}$ & $\begin{array}{c}\text { Number of groups } \\
\text { of antigen-bearing } \\
\text { cells in white pulp }\end{array}$ & $\begin{array}{c}\text { Average number of } \\
\text { cells per group }\end{array}$ & $\begin{array}{c}\text { Number of } \\
\text { germinal centres } \\
\text { containing cells }\end{array}$ & $\begin{array}{c}\text { Average number of } \\
\text { cells per germinal } \\
\text { centre }\end{array}$ \\
\hline $24 \mathrm{hr}$ & 1 per $543 \mathrm{~mm}^{2}$ & 9 & 0 & 0 \\
$28 \mathrm{hr}$ & 20 per $295 \mathrm{~mm}^{2}$ & 8 & 0 & 0 \\
$44 \mathrm{hr}$ & 39 per $236 \mathrm{~mm}^{2}$ & 9 & 23 per $236 \mathrm{~mm}^{2}$ & 0 \\
7 days & 0 & 0 & $\cdots$ & $44-60$ \\
\hline
\end{tabular}

The morphology of the antigen-bearing cells is shown in fig. $7 a$ and $b$ as a high-power magnification of the central region of a germinal centre from a chicken spleen at 6 days after injection of HSA. The appearance of the fluorescence suggests that the antigen occurs at highest concentration at the surface of the cell body and over the surface of elongated branching cell-processes. In 
general such fluorescent cells are separated from each other by non-fluorescent cells closely applied to the cell surface or cell-processes of the antigen-bearing cells. Isolated streaks or dots of fluorescence lie between or away from the obvious antigen-bearing cell bodies. These could be interpreted as the cytoplasmic extensions of antigen-bearing cells outside the plane of the section. Simultaneously with the appearance of antigen-bearing cells at $24 \mathrm{hr}$, or more commonly at $32 \mathrm{hr}$ in the white pulp, cells containing anti-HSA are seen for the first time in the red pulp. They have the configuration of immature and mature plasma cells (fig. 8). These cells are confined to the red pulp and are never seen adjacent to the antigen-bearing cells of the white pulp, nor do they resemble them morphologically. The number of these anti-HSA-containing cells and the intensity of their fluorescence increase until it reaches a maximum on the 4 th or 5th day after the injection. Thereafter the number of these cells decreases rapidly, and they are no longer detectable in the red pulp after the 10th to 12th days. After the 15th day cells containing anti-HSA make their appearance in a few of the germinal centres in which antigen can still be detected. From fig. 3 it will be seen that 4-5 days elapsed between the disappearance of the plasma cells containing anti-HSA from the red pulp and the development of anti-HSA-containing cells in the germinal centres. These late-appearing antibody-containing cells of the germinal centres (fig. 9) are small $(9-10 \mu \mathrm{m}$ diameter) round or polygonal cells, often closely packed together in a segment of the germinal centre, but occasionally so numerous that the centre is largely made up of such fluorescent cells (excluding the antigen-bearing cells) so that it stands out as a fluorescent oval against the dark non-fluorescent background of the surrounding white and red pulp. The fluorescence of such cells extends evenly throughout the cytoplasm, with occasional spots of fluorescence within the otherwise dark circle of the nuclear area. They therefore differ sharply in morphology from the antigen-bearing cells.

\section{The distribution of $7 S$ immunoglobulin in the chicken spleen}

The spleens of at least 20 birds were examined after staining with fluorescent anti-chicken-7S-immunoglobulins. This demonstrated the presence of large clusters of plasma cells in the red pulp containing $7 \mathrm{~S}$ immunoglobulin. But $7 \mathrm{~S}$ immunoglobulin was also present in all the germinal centres of the sections examined (fig. 10). Its cellular distribution produced an appearance identical to that of the antigen-bearing cells that have already been described in germinal centres from 4 days onwards. In several instances the pattern of antigen was photographed. The fluorescence of the germinal centre was then totally quenched by a further 10 minutes' exposure to ultraviolet rays and this was checked by a further photograph. After exposure of the section to fluorescein-labelled rabbit anti-chicken-7S-globulin and subsequent photography, the resulting pattern of fluorescence could be checked in detail against the pattern of antigen in the previous photograph. All cells with antigen in the first photograph also appeared, with brighter fluorescence, in the second. Additional images of cells also appeared in the second photograph suggesting that the antibody : antigen 


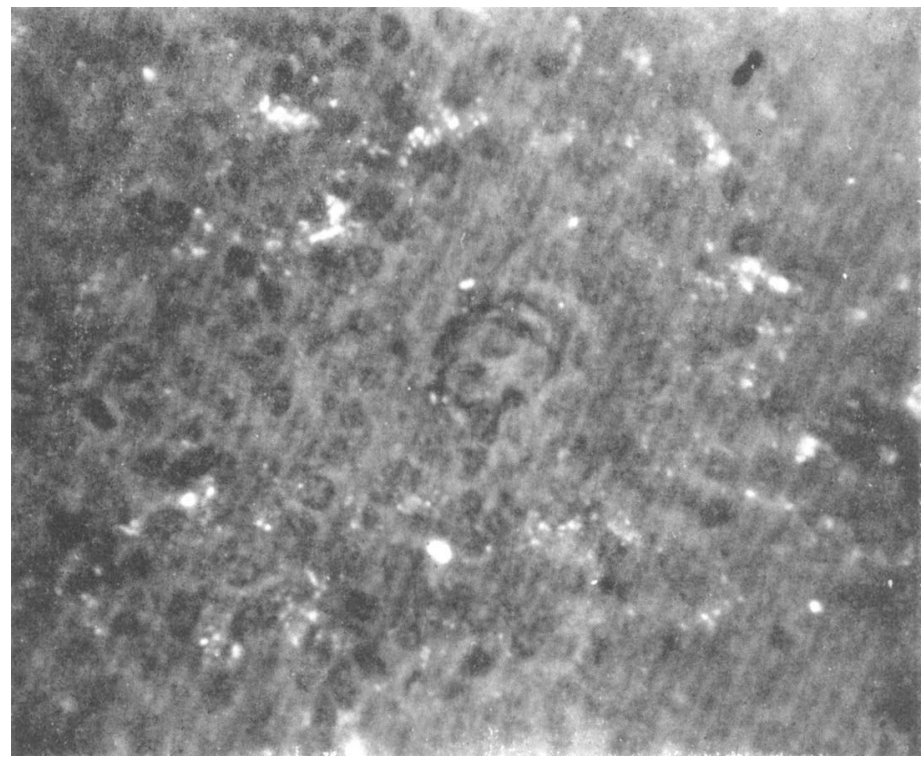

FIG, 4.- Chicken spleen. Bird given injection of $10 \mathrm{mg}$ HSA 2 days previously. Fluorescence micrograph: single layer technique with fluorescein-labelled anti-HSA. Granular foci of fluorescence surround a penicillary arteriole of the white pulp, denoting HSA localised to dendritic cells. $\times 810$.

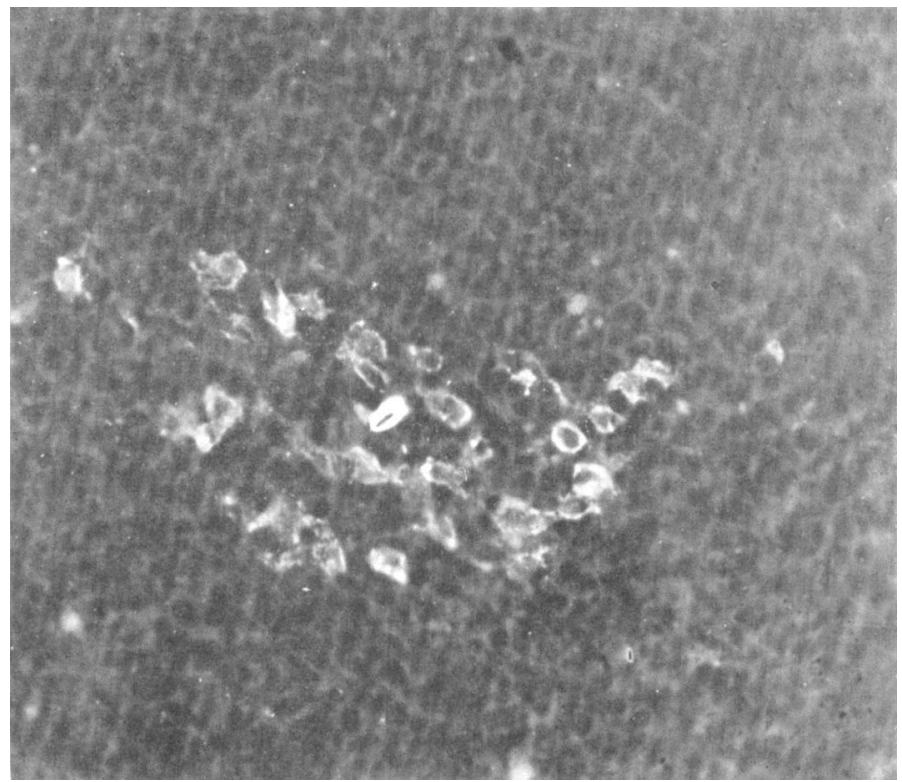

FIG. 5.- Chicken spleen. Bird given injection of $10 \mathrm{mg}$ HSA 5 days previously. Fluorescence micrograph: single layer technique with fluorescein-labelled anti-HSA. Note antigen-bearing cells within the irregular outline of an early germinal centre. $\times 900$. 


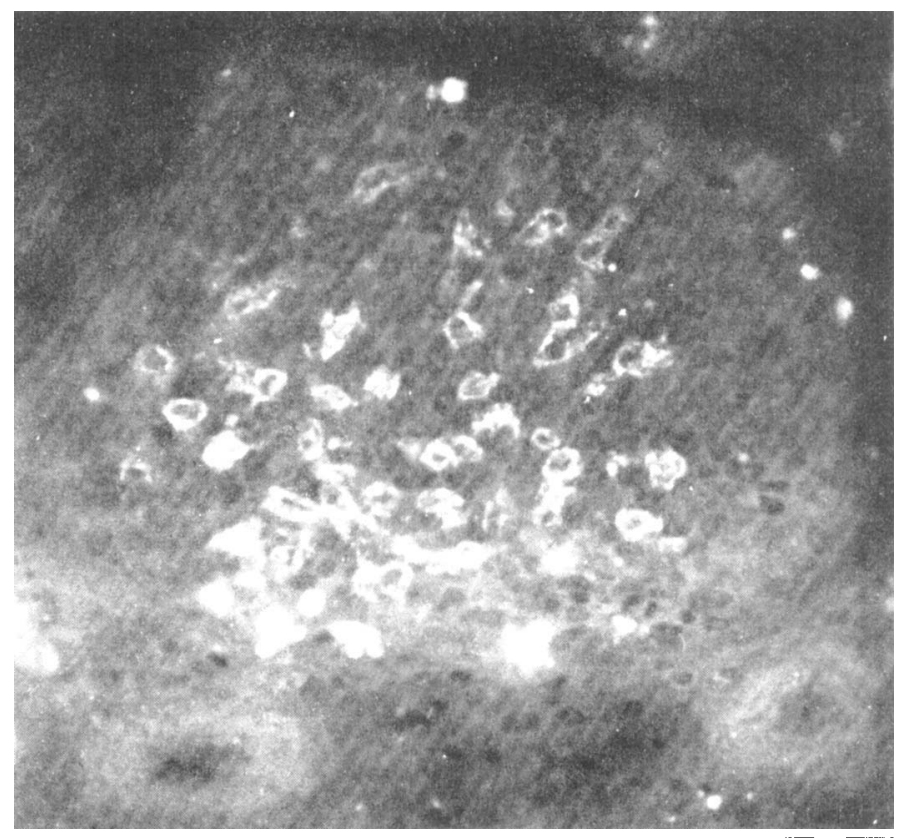

FIG. 6.- Chicken spleen. Bird given injection of $10 \mathrm{mg}$ HSA 7 days previously. Fluorescence micrograph: single layer technique with fluorescein-labelled anti-HSA. Note antigen-bearing cells scattered over the oval outline of a germinal centre that is larger than that in fig 5 . The bright oval solid masses running along the lower limit of the centre were orange naturalfluorescent bodies, which are not uncommonly seen at the periphery of a germinal centre at this stage of its development. $\times 765$.

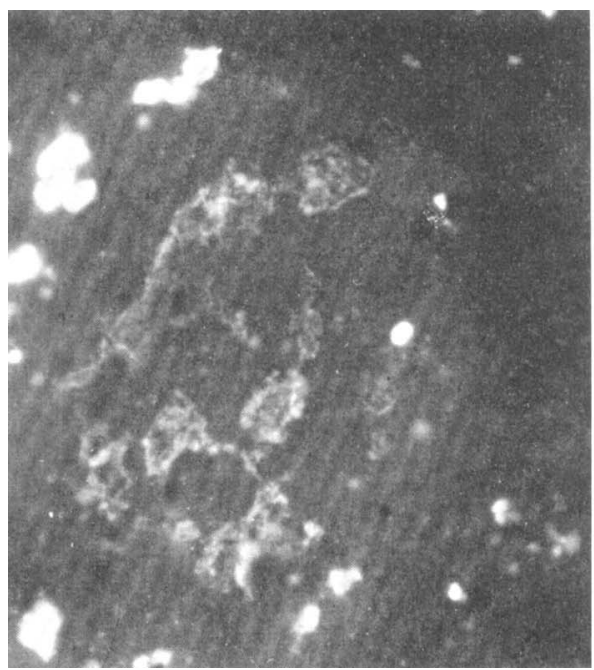

FIG. 7a.-Details of antigen-bearing cells. Note fluorescence outlining surface of perikaryon and dendritic cytoplasmic processes. Natural fluorescent globules shown above right and left are at periphery of germinal centre.

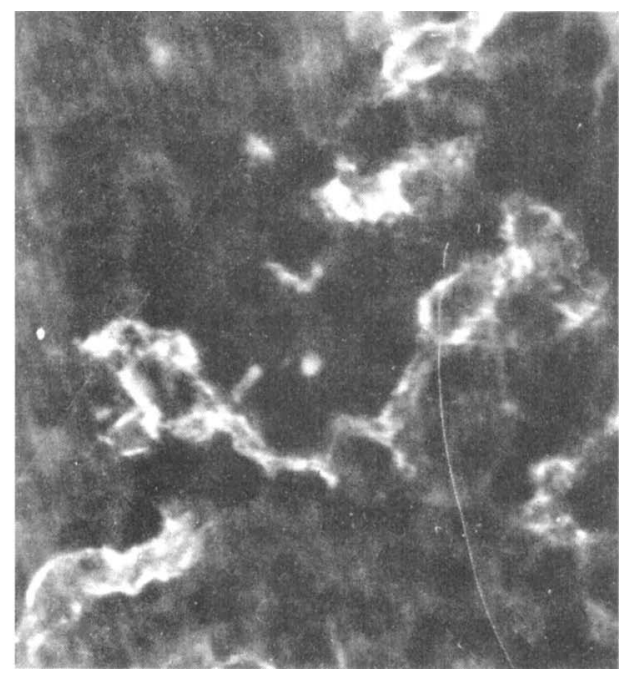

FIG. 7b.-Details of localisation of fluoresceinlabelled anti-HSA at the surface of the perikaryon and cytoplasmic processes of dendritic cells.

Fig. 7.-Part of germinal centre. Fluorescence micrography. $\times 1000$. 


\section{Plate IV}

Frg. 8.-Red pulp of chicken spleen at 4 days after intravenous injection of $10 \mathrm{mg}$ HSA. Fluorescence micrograph: sandwich technique with HSA and fluorescein-labelled rabbit anti-HSA. Note anti-HSA containing mature and immature plasma cells in red pulp strand. $\times 900$.

Fig. 9.-Chicken spleen at 14 days after intravenous injection of $10 \mathrm{mg}$ HSA. Fluorescence micrograph: sandwich technique with HSA and fluorescein-labelled anti-HSA to demonstrate antibody. Note sharply demarcated oval outline of germinal centre, within which the majority of the cells show a cytoplasmic content of anti-HSA. The bright, solid oval masses are natural fluorescence at the periphery of the germinal centre. $\times 765$.

Fig. 10.-Chicken spleen at 6 days after an intravenous injection of $10 \mathrm{mg}$ of HSA. Fluorescence micrograph: single layer technique with fluorescein-labelled rabbit anti-chicken globulin. The dendritic cells of the germinal centre have their surfaces outlined by a finely granular pattern of fluorescence. $\times 765$. 
LOCALISATION OF PROTEIN ANTIGEN IN SPLEEN

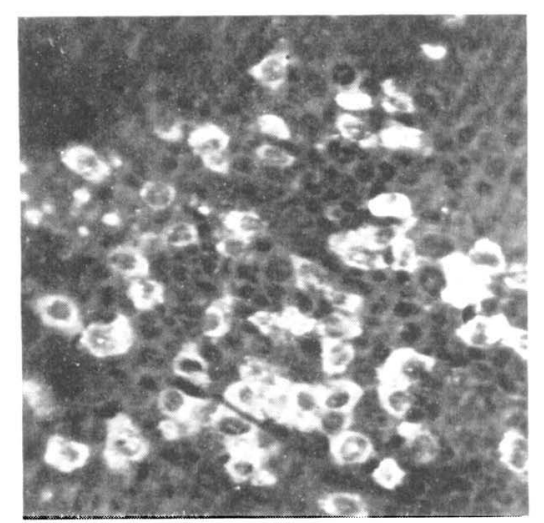

FIG. 8.

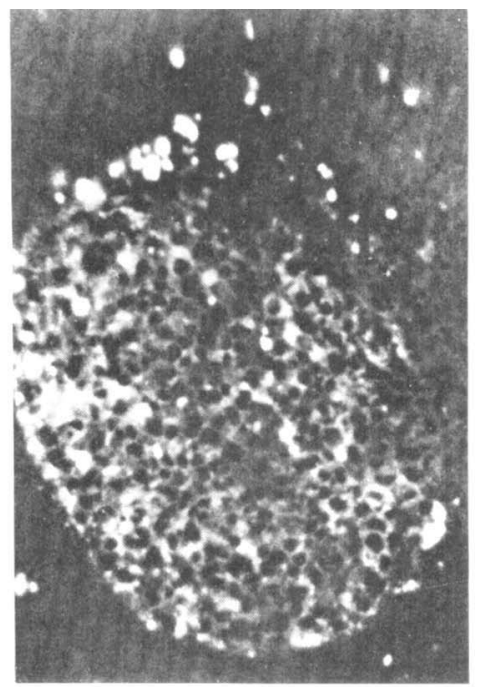

FIG. 9.

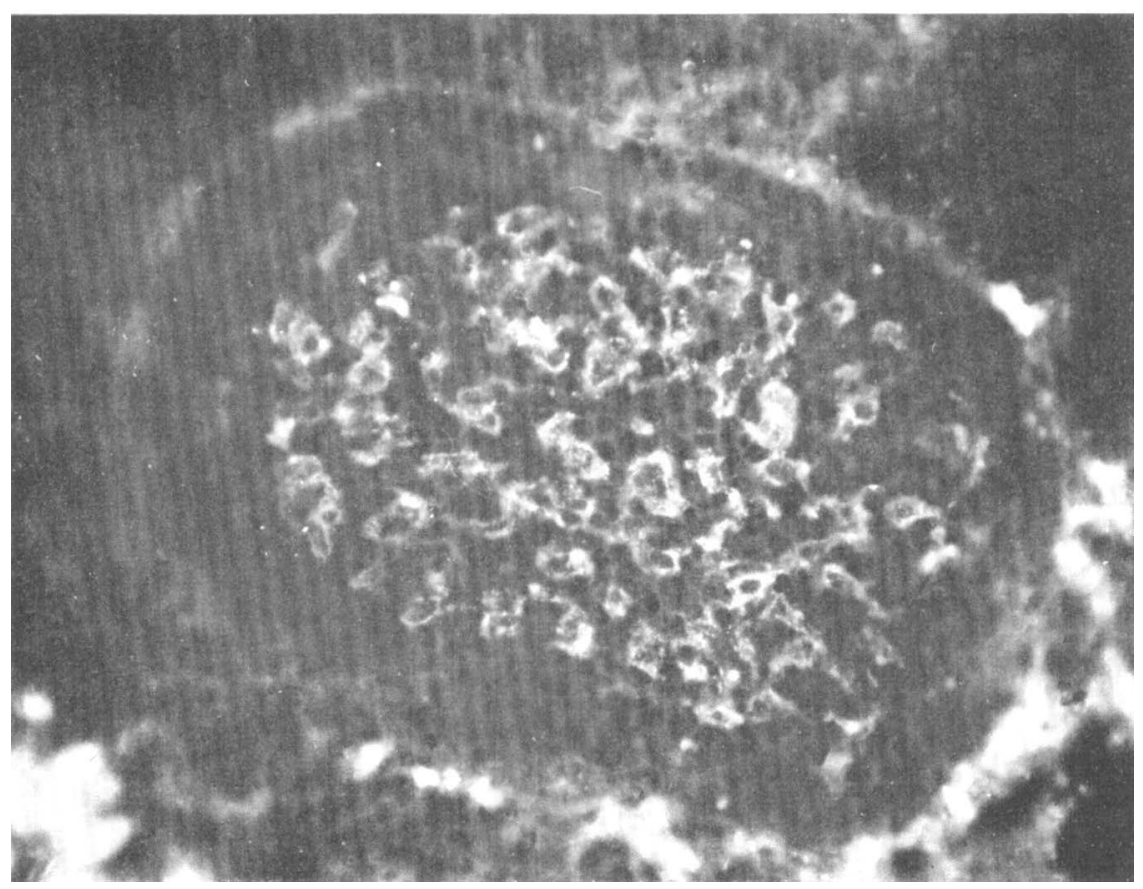

FIG. 10. 


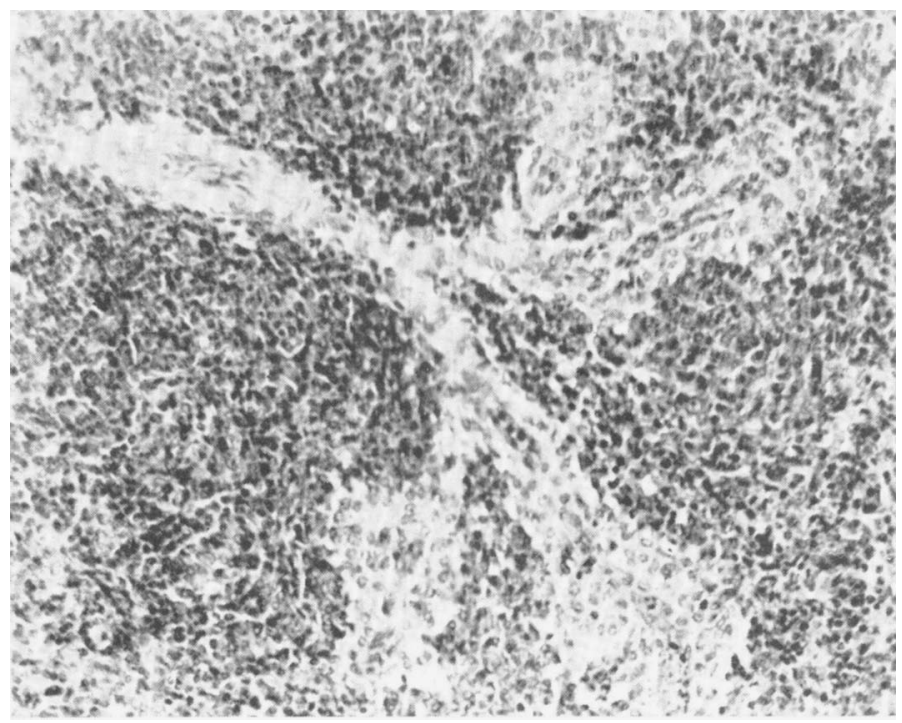

FIG. 12a.-Leash of penicillary arterioles radiating from central arteriole of white pulp (top left). At the periphery of the white pulp each vessel ends in an expanded ellipsoidal segment (Schweigger-Seidel sheath). Paraffin section. Haematoxylin and eosin. $\times 420$.

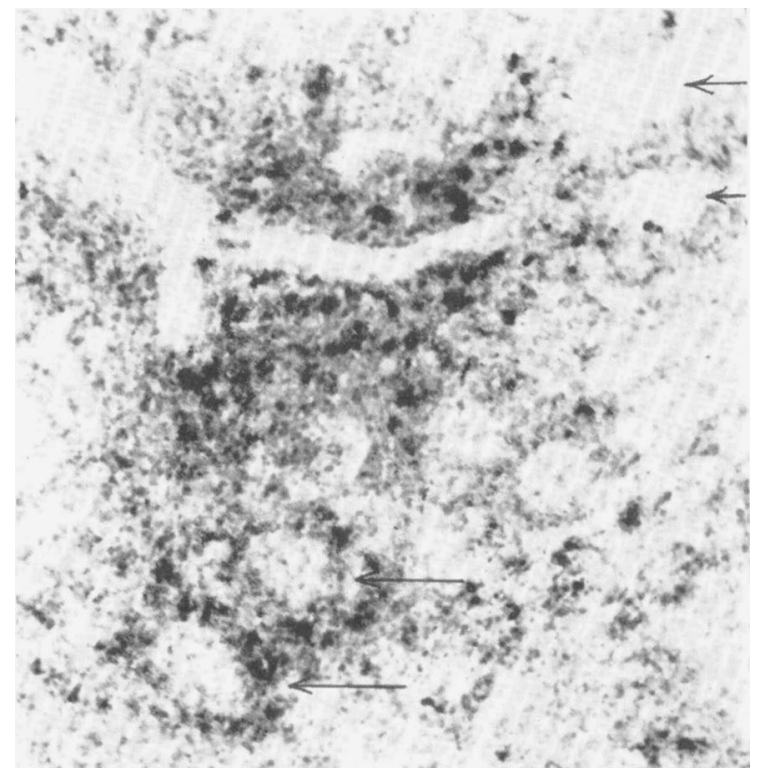

FIG. 12b.-Four ellipsoids (Schweigger-Seidel sheaths) are shown (arrowed). The periphery of the lower two ellipsoids is outlined by a zone of increased grain-density which includes a few denser foci, which are interpreted as due to 125I-HSA localised to individual cells. Similar dense foci denoting HSA-bearing cells are distributed along the penicillary arterioles, one of which is shown running to the right from its origin at the bifurcation of the central arteriole, shown at top left corner. Note that no HSA-bearing cells extend along the central arteriole itself. Autoradiograph. $\times 315$.

FIG. 12.-Chicken spleen at $88 \mathrm{hr}$ after intravenous injection of $40 \mu \mathrm{g}$ of 125I-HSA. 
LOCALISATION OF PROTEIN ANTIGEN IN SPLEEN

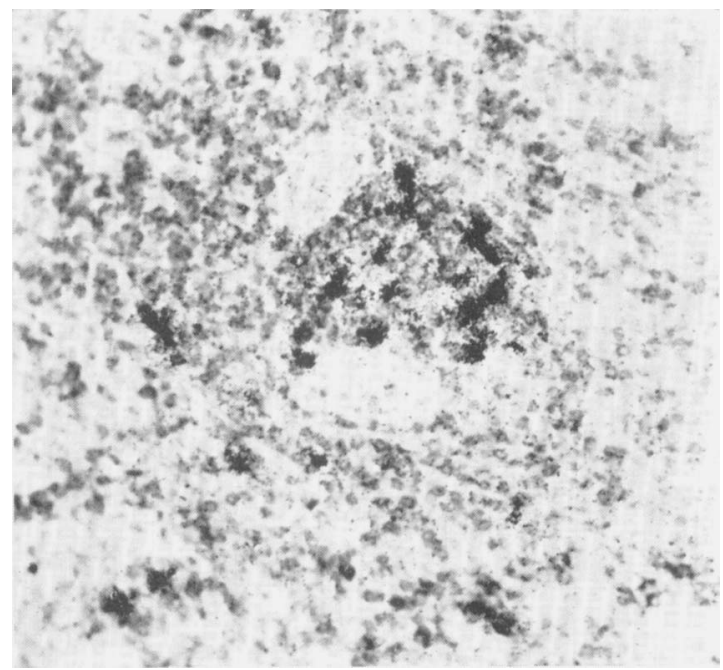

FIG. 13a.-Collection of approximately twelve grain-foci denoting 125I-HSA-bearing dendritic cells that have formed a cluster in the angle between two penicillary vessels-the anlage of a germinal centre. Autoradiograph. $\times 450$.

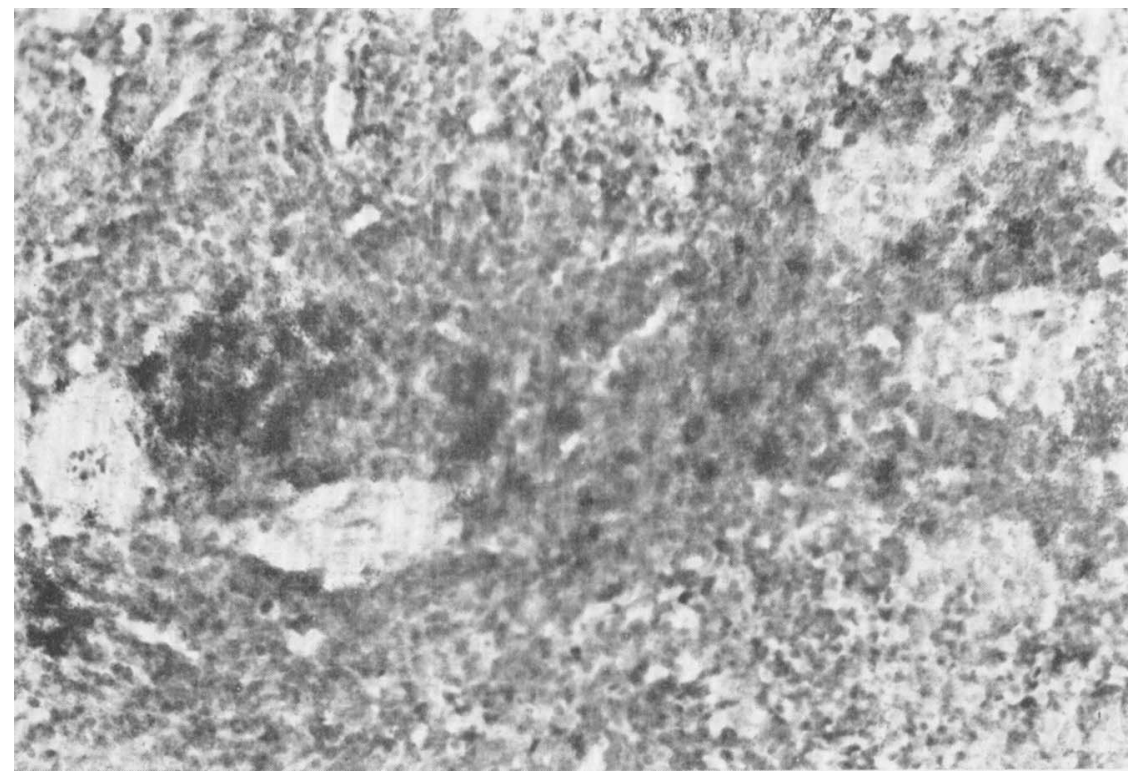

FIG. 13b.-Grain-foci of 125I-HSA distributed along a penicillary arteriole and also forming a cluster within the anlage of a germinal centre (shown at left, in the angle between two penicillary arterioles). At right are shown three ellipsoids which appear as oval areas of paler-staining cells. Autoradiograph. $\times 525$.

FIG. 13.-Chicken spleen at $88 \mathrm{hr}$ after a single intravenous injection of 125I-HSA. 


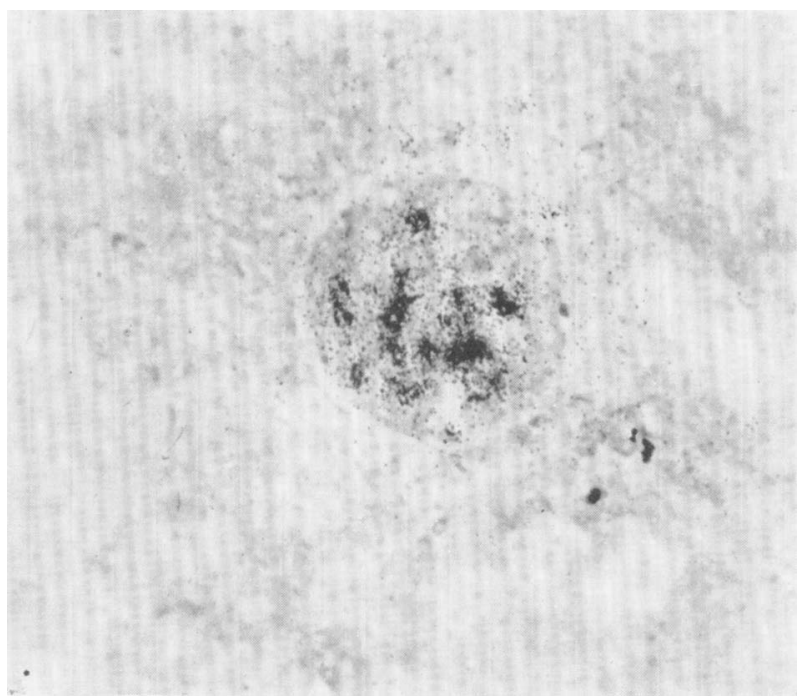

FIG. 14a.-The circular outline of a germinal centre includes approximately ten grain-foci denoting localisation of HSA to dendritic cells. Note that the surrounding white and red pulp are devoid of similar foci of localised antigen. Autoradiograph. $\times 400$.

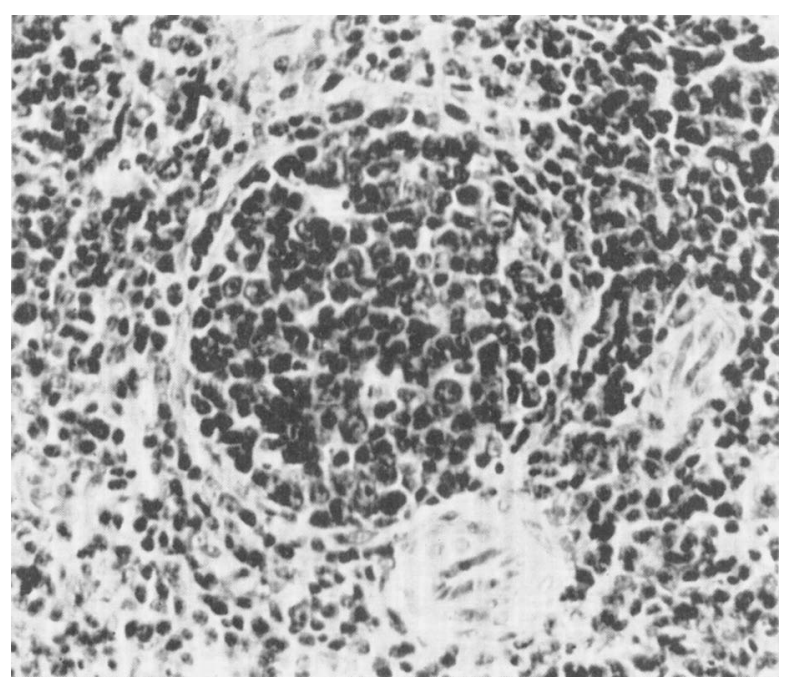

FIG. 14b.-Similar germinal centre from paraffin-embedded chicken spleen. HE. $\times 560$.

FIG. 14.-Chicken spleen at 6 days after a single intravenous injection of $40 \mu \mathrm{g} 125 \mathrm{I}-\mathrm{HSA}$. 
ratio of the cell-associated complexes was such as to render the antigen undetectable by the fluorescence method.

TABLE II

Summary of experiments to induce specific tolerance to HSA in chickens: effect on serum antibody levels and detection of HSA by immunofluorescence in tissue sections

\begin{tabular}{|c|c|c|c|c|c|c|c|c|}
\hline \multirow{3}{*}{$\begin{array}{l}\text { Experi- } \\
\text { ment }\end{array}$} & \multirow{3}{*}{$\begin{array}{c}\text { Animal } \\
\text { no. }\end{array}$} & \multirow{3}{*}{$\begin{array}{l}\text { Kinetics of } \\
\text { elimination } \\
\text { of test dose } \\
\text { of } 131 \text { I-HSA }\end{array}$} & \multirow{3}{*}{$\begin{array}{c}\text { Time- } \\
\text { interval } \\
\text { after } \\
\text { injection } \\
\text { of HSA } \\
\text { (days) }\end{array}$} & \multirow{3}{*}{$\begin{array}{c}\mathrm{ABC}_{30} \\
\text { ( } \mu \mathrm{g} \text { per ml) } \\
\text { at day of } \\
\text { killing }\end{array}$} & \multirow{3}{*}{$\begin{array}{l}\text { Number } \\
\text { of days } \\
\text { after } \\
\text { injection } \\
\text { of HSA }\end{array}$} & \multicolumn{3}{|c|}{ Fluorescence microscopy of spleen } \\
\hline & & & & & & \multirow{2}{*}{ Antigen } & \multicolumn{2}{|c|}{ Antibody in } \\
\hline & & & & & & & red pulp & $\begin{array}{c}\text { germinal } \\
\text { centre }\end{array}$ \\
\hline A & $\begin{array}{l}\text { B38 } \\
\text { G36 } \\
\text { G1 } \\
\text { G2 } \\
\text { Control } \\
\text { Control }\end{array}$ & $\begin{array}{l}\text { Tolerant* } \\
\text { Tolerant } \\
\text { Tolerant } \\
\text { Tolerant } \\
\text { Immunet } \\
\text { Immune }\end{array}$ & $\begin{array}{l}4 \\
5 \\
4 \\
5 \\
4\end{array}$ & $\begin{array}{l}\text { Nil } \\
\text { Nil } \\
\text { Nil } \\
15 \\
\text { Nil }\end{array}$ & $\begin{array}{l}4 \\
4 \\
5 \\
4 \\
5 \\
4\end{array}$ & $\begin{array}{l}\text { None } \\
\text { None } \\
\text { None } \\
\text { None } \\
\text { Present } \\
\text { Present }\end{array}$ & $\begin{array}{l}\text { None } \\
\text { None } \\
\text { None } \\
\text { None } \\
\text { Present } \\
\text { Present }\end{array}$ & $\begin{array}{l}\text { None } \\
\text { None } \\
\text { None } \\
\text { None } \\
\text { None } \\
\text { None }\end{array}$ \\
\hline $\mathbf{B}$ & $\begin{array}{l}\text { R42 } \\
\text { Y27 } \\
\text { (Immune) } \\
\text { G31 } \\
\text { (Control) }\end{array}$ & $\begin{array}{l}\text { Tolerant } \\
\text { Accelerated } \\
\text { immune } \\
\text { Immune }\end{array}$ & $\begin{array}{l}4 \\
4 \\
4\end{array}$ & $\ldots$ & $\begin{array}{l}4 \\
4 \\
4\end{array}$ & $\begin{array}{l}\text { None } \\
\text { None } \\
\text { Present }\end{array}$ & $\begin{array}{l}\text { None } \\
\text { Present } \\
\text { Present }\end{array}$ & $\begin{array}{l}\text { None } \\
\text { None } \\
\text { None }\end{array}$ \\
\hline $\mathrm{C}$ and $\mathrm{D}$ & $\begin{array}{l}\text { R3 } \\
\text { R4 } \\
\\
\text { Control } \\
\text { R37 } \\
\text { R39 } \\
\text { R40 } \\
\end{array}$ & $\begin{array}{l}\text { Tolerant } \\
\text { Immune } \\
\text { (broken tol- } \\
\text { erance) } \\
\text { Immune } \\
\text { Tolerant } \\
\text { Tolerant } \\
\text { Immune } \\
\text { (broken tol- } \\
\text { erance) } \\
\text { Immune }\end{array}$ & $\begin{array}{c}7,8,13 \\
\\
8 \\
8 \\
\cdots \\
\cdots\end{array}$ & $\begin{array}{l}0 \cdot 15 \\
1 \cdot 5 \\
\cdots \\
\cdots\end{array}$ & $\begin{array}{l}8 \\
\cdots \\
\cdots \\
\cdots\end{array}$ & $\begin{array}{c}\text { None } \\
\text { None } \\
\ldots \\
\ldots\end{array}$ & $\begin{array}{l}\text { Present } \\
\ldots \\
\ldots \\
\ldots\end{array}$ & $\begin{array}{c}\text { None } \\
\ldots \\
\ldots \\
\ldots \\
\\
\text { Present } \\
\ldots\end{array}$ \\
\hline
\end{tabular}

* Tolerant type of antigen elimination $=$ exponential rate of decrease of 131I-HSA maintained for 7 days.

+ Immune type of antigen elimination $=$ increased rate of disappearance of 131I-HSA starting at day $3-4$.

+ Accelerated type of antigen elimination $=$ increased rate of disappearance of 131I-HSA from day 1 (previously immunised bird).

The effect of acquired tolerance to HSA on the cellular response

Sections of spleen were examined from chickens that had been rendered tolerant to HSA by a course of intraperitoneal injections of HSA extending from hatching as described in Materials and methods. The completeness of tolerance for HSA was determined by observing the elimination of ${ }^{131}$ I-HSA for a period of 8 days by whole-body counting. In fully tolerant birds a uniformly exponential rate of elimination of ${ }^{131}$ I-HSA was maintained (half-life, 
1.25 days). In control birds with approximately the same initial rate of elimination (half-life, 1.25 days) the rate increased after the 4th day because of the onset of an immunological response. In this part of the curve half-lives of 0.4-0.6 days were found. In some cases Farr tests to detect the presence of circulating antibody were also done.

Some chickens were found to have "broken" tolerance and showed immune elimination of 131I-HSA and the presence of circulating anti-HSA.

Table II summarises the experiments performed to investigate the effect of tolerance on the cellular immune response. In experiment A, $10 \mathrm{mg}$ 131I-HSA was injected into each of 6 chickens and the subsequent elimination curve plotted. Complete tolerance was found in 4 test birds; the 2 control birds both gave an immune elimination curve. A second dose of $10 \mathrm{mg}$ HSA was given 8 days afterwards and the birds were killed 4 or 5 days later. Sections of the spleens of the control birds stained by the sandwich method show the presence of anti-HSA-containing plasma cells in the red pulp and of antigenbearing cells in the germinal centres. No HSA or anti-HSA is detectable at sites within any of the spleen sections from the tolerant birds. In experiment $B$, 3 chickens were tested for tolerance. One of the chickens that had been preimmunised with HSA had demonstrable circulating antibody and was shown to eliminate the test dose of $131 \mathrm{I}-\mathrm{HSA}$ at a high rate from the beginning of the test. Another bird appeared by the test elimination of 131I-HSA to be fully tolerant. The third (normal) bird was included as a control. At the completion of the 8 days required for the test elimination of 131I-HSA, a dose of $10 \mathrm{mg}$ HSA was injected intravenously and the birds were killed 4 days later. Both non-tolerant birds, which yielded immune-type elimination curves for 131I-HSA (R4 and R40 in fig. 11), show in spleen sections numerous collections of antiHSA-containing plasma cells within the red-pulp, and one of the two shows the presence of numerous antigen-bearing cells within the germinal centres. Contrariwise, the spleen sections from the tolerant bird show complete absence of anti-HSA-containing plasma cells and of HSA-bearing cells within the germinal centres or elsewhere.

The birds of experiments C and D illustrated the effect of spontaneously broken tolerance on the localisation of antigen and the occurrence of antibodycontaining cells within the spleen. These birds were treated to induce tolerance by a schedule of injections of HSA identical with that used for the successful establishment of tolerance in other birds. The reason for the lack of complete tolerance in these birds was not known. The test elimination of 131I-HSA revealed an immune-type elimination curve and the subsequent production of circulating anti-HSA. Examination of sections of the spleen 5 or 8 days later shows the presence of collections of anti-HSA-containing plasma cells in the red pulp, and in one of the chickens both antibody-containing and antigenbearing cells are present within the splenic germinal centres.

Therefore it was uniformly the case that the injection of $10 \mathrm{mg}$ of HSA intravenously into fully tolerant birds failed to induce localisation of antigen to cells in the white pulp (including germinal centres) or the appearance of anti-HSA-containing plasma cells in the red pulp. These birds with "spon- 
taneously broken" tolerance, normal control and previously immunised birds all responded to the injection of $10 \mathrm{mg}$ HSA by the appearance of anti-HSAcontaining plasma cells and most of these also showed antigen-localisation.

\section{Autoradiographic localisation of 125 I-HSA within the spleen}

For the autoradiographic localisation of antigen within sections of spleen tissue, $40 \mu \mathrm{g}$ of $125 \mathrm{I}-\mathrm{HSA}$ was injected by the intravenous route. Although the amount of HSA was much smaller than that used for the previous histological

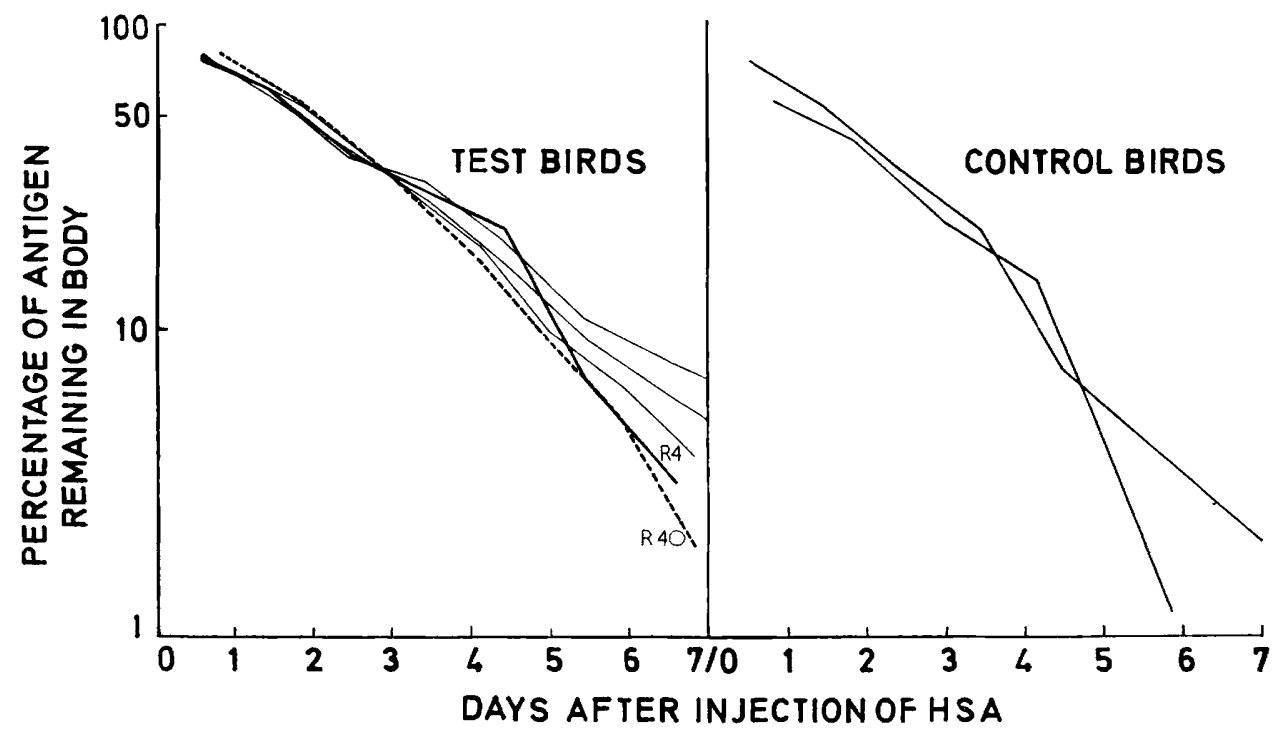

FIG. 11.-Elimination of a test dose of 131I-HSA in determination of completeness of specific immunological tolerance to HSA. Ordinate: percentage of antigen remaining in whole body (logarithmic scale). Abscissa: time in days. "Test" birds were treated from day of hatch with HSA over a dosage schedule designed to induce complete tolerance (see text p. 66). In case of R4 and R40 complete tolerance was not achieved. "Control " birds were normal birds, which eliminated the test dose at an initial half-life rate of 1.25 days, which increased after the 4 th day to a half-life of $0 \cdot 4-0 \cdot 6$ days.

observations with the fluorescent antibody method $(10 \mathrm{mg})$, the sites of localisation in autoradiographs prepared from $4 \mu \mathrm{m}$ cryostat sections of spleens obtained at 16, 40 and $88 \mathrm{hr}$ and 6 and 7 days after injection are similar.

No antigen detectable in autoradiographs of spleen by grain-clusters due to the 125I label can be seen in the sections at $16 \mathrm{hr}$ after injection. At $40 \mathrm{hr}$ antigen appears associated with sparse cells distributed along the branches of the central arterioles of the white pulp. At $88 \mathrm{hr}$ the numbers of such antigenbearing cells have increased approximately ten-fold. They have a sharply defined distribution along the vessels of the white pulp and in the marginal zone (fig. 12a). Fig. $12 b$ shows a few such cells situated just beyond the outer edge of the ellipsoids in the marginal zone of the spleen. Similar cells are distributed along the branches of the central arteriole within the white pulp of the spleen, but do not extend more proximally than the point of bifurcation of the main central 
arteriole. The antigen-bearing cells are present at points just beyond the adventitia of the branches of the central arteriole and further out among the lymphocytes of the surrounding white pulp. At $88 \mathrm{hr}$ small clusters of approximately

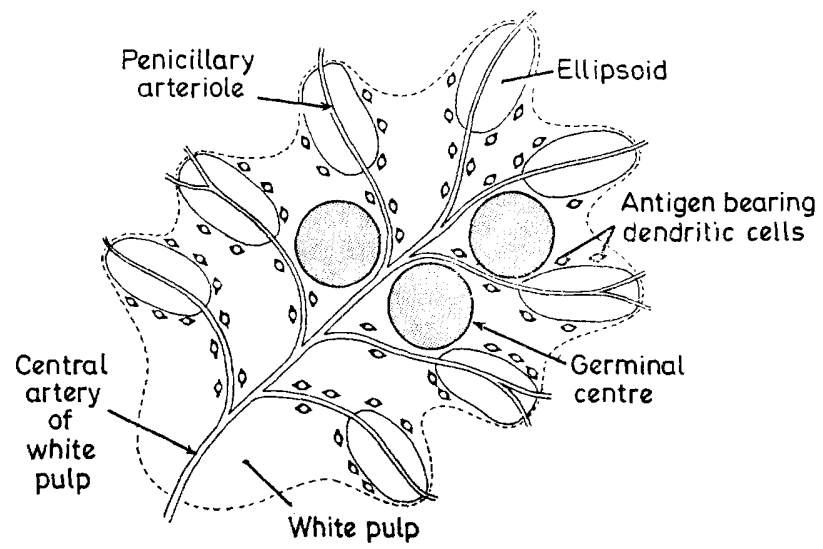

FIG. $15 a .-40 \mathrm{hr}$ after injection. Antigen-bearing cells are present in white pulp at periphery of Schweigger-Seidel sheaths (ellipsoids) and along penicillary arterioles.

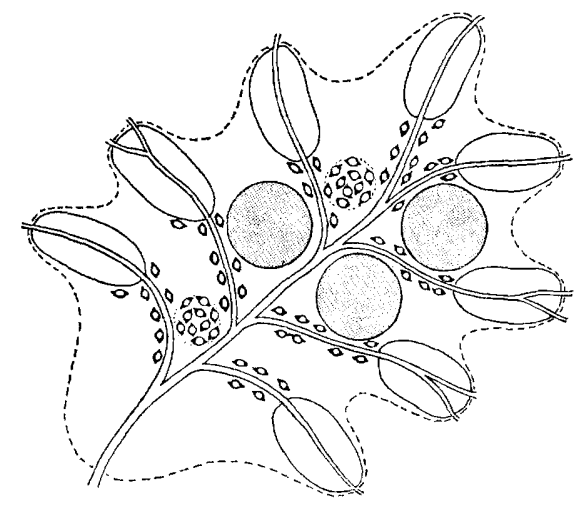

FIG. $15 b .-90 \mathrm{hr}$ after injection. Early aggregations of antigen-bearing cells within early germinal centres at bifurcations of the central arteriole of the white pulp. Antigen-bearing cells still present along penicillary arterioles.

FIG. 15.-Diagrammatic summary of combined findings from immunofluorescence and autoradiography at the cellular migrations of antigen-bearing "dendritic cells" in the chicken spleen at various time-intervals after an intravenous injection of $10 \mathrm{mg}$ HSA.

12 labelled cells are present. Fig. $13 a$ and $b$ shows that these are closely related to the branches of the central arteriole of the white pulp, being typically localised in the angle formed by two diverging branch arterioles. Such clusters of antigen-bearing cells presumably represent the early germinal centre, but the organisation of cells at this stage is not such as to produce the sharp peripheral demarcation from the surrounding white pulp that characterises the centre at later stages of development. In sections stained with methyl green-pyronin it is possible to see that the cytoplasm of the cells enclosed in the clusters (lymphocytes) has a higher RNA content than the surrounding white-pulp lymphocytes. 
No mitotic figures are to be seen within the clusters at this time after injection of antigen.

At 6 days all labelled antigen-bearing cells of the white pulp that are present are within the territory of obvious and typical germinal centres with

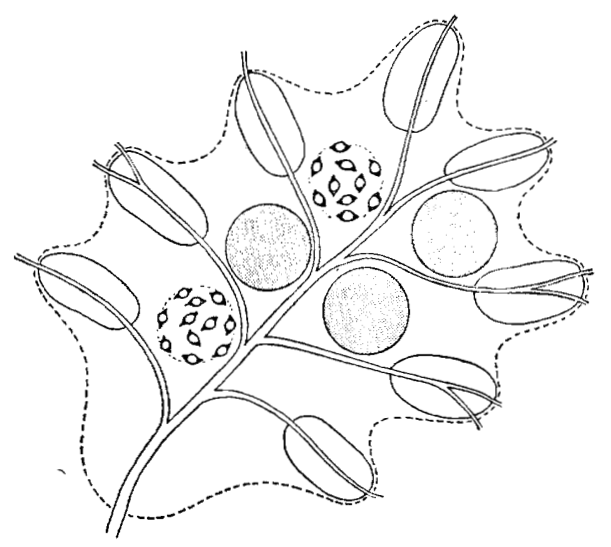

FIG. 15c.-6 days after injection. All antigen-bearing cells within enlarged outlines of germinal centres.

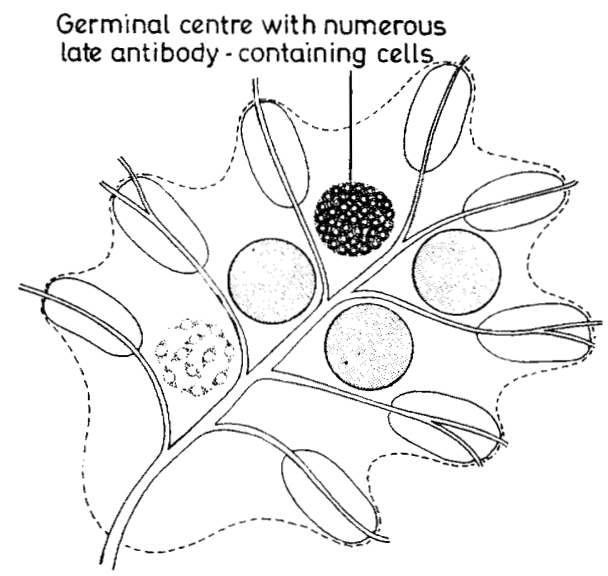

FIG. 15d.-20 days after injection. Antigen-bearing cells still visible (though giving fainter reactions for the presence of antigen) in germinal centres. Some germinal centres contain numerous lymphocytes with a cytoplasmic content of antibody: "late antibody-containing cells".

FIG. 15.-Diagrammatic summary of combined findings from immunofluorescence and autoradiography of the cellular migrations of antigen-bearing "dendritic cells" in the chicken spleen at various-time intervals after an intravenous injection of $10 \mathrm{mg} \mathrm{HSA}$.

well-defined circular peripheral margins (fig. $14 a$ and $b$ ). Germinal centres containing labelled cells number 1 or 2 per total cross-section of the spleen. They are, therefore, far fewer in number than antigen-containing centres as revealed by the fluorescent antibody method in parallel experiments that have been described above. The amounts of injected antigen were, however, 250 times smaller in the experiments that involved the autoradiographs. 
The cellular events within the chicken spleen are summarised diagrammatically in fig. $15 a, b, c$ and $d$. These diagrams show the migration of scattered antigen-bearing cells into germinal centres and the subsequent later production of specific antibody by a proportion of these centres.

\section{DISCUSSION}

Chickens given an injection of HSA for the first time at 6-14 wk of life produce a surprisingly rapid and short peak of antibody; the serum level rises on the 4th day and increases to a peak at 8 or 9 days; thereafter a rapid decline occurs so that very low levels are recorded from the 15 th day onwards. The immunofluorescence method shows that anti-HSA-containing cells of the plasma cell series appear in the red pulp of the spleen as early as $24 \mathrm{hr}$ after injection. The number of such cells increases up to the 6th or 7th day and subsequently decreases so that very few are there at the 12 th day after injection. Therefore, the curve of serum antibody appears to lag between 1 and 2 days after the similar curve of increase and decrease of plasma cells in the splenic red pulp. The kinetics of the rapid decline of immunoglobulin in the period 10-14 days is compatible with the observed half-life for homologous chicken globulin of $2 \cdot 0-2 \cdot 5$ days, if we assume that the cellular production of anti-HSA falls to insignificant levels after the 9 th day.

The use of the immunofluorescence technique for detecting HSA in frozen sections of spleen shows that this antigen is regularly associated with scattered cells in the white pulp $32 \mathrm{hr}$ after injection, although a few of the birds that were killed at $24 \mathrm{hr}$ also show scanty antigen-bearing cells in the white pulp. At later time-intervals (up to 3 days) antigen-bearing cells within the white pulp increase in number, but none is present at this time within the outline of the germinal centres. The antigen-bearing cells are distributed along the course of the penicillary branches of the central artery of the white pulp and arranged singly and as small groups around and just beyond the adventitia of the vessel.

At later time-intervals after injection (i.e., from the $3 \mathrm{rd}$ day), antigenbearing cells are present as sharply defined collections scattered among the dividing lymphoid cells of small germinal centres. The appearance at the 5 th and 7 th day (as shown in figs. 5 and 6) clearly shows that the germinal centre increases rapidly in size at this time and already at the 6th day assumes a regularly circular, sharply defined outline. At the 4th day, antigen-bearing cells are distributed partly inside small germinal centres and partly scattered along the penicillary arterioles of the white pulp (fig. 14).

At 6 days all antigen-bearing cells are within the now enlarged and circular outlines of germinal centres. It is clear that the earliest time at which the process of inclusion of antigen into newly formed germinal centres can be recognised is the 3rd day. At the 3rd and 4th day antigen-bearing cells are never seen in the other larger and sharply defined germinal centres that are present throughout the splenic white pulp, but are visible only in uniformly small centres. Germinal centres increase in size up to the 8th day at least, and at this time most of the germinal centres with a content of antigen-bearing cells 
are large centres (in the range of $75-100 \mu \mathrm{m}$ diameter). With the doses of HSA usually used in this study (i.e., $10 \mathrm{mg}$ ) about one-third to one-quarter of the germinal centres show a content of antigen. Lower doses of antigen (i.e., $40 \mu \mathrm{g}$ HSA) cause the appearance (in autoradiographs) of far fewer centres with a content of antigen, so that these form a lower proportion of the total. These facts are consistent with the hypothesis that each germinal centre that includes antigen-bearing cells had been formed recently and de novo. There is nothing to suggest that the antigen-bearing cells, originally scattered throughout the white pulp, migrate into pre-existing germinal centres in the period 2-5 days after injection of HSA.

The appearance of antigen-bearing cells scattered evenly over the crosssection of the germinal centre (so that individual cells are on all sides separated by non-fluorescent lymphocytes) is constantly maintained in sections of tissue taken up to $6 \mathrm{wk}$ after injection of antigen. The fluorescence of antigenbearing cells becomes progressively more difficult to discern in centres after the 11 th day, but is still visible in some birds killed as long as 6 wk after injection of HSA.

By the use of fluorescein-labelled anti-chicken-globulin it was possible to obtain a pattern of fluorescence identical with the pattern of antigen within an individual germinal centre, but present in all of the germinal centres of the spleen. It is inferred from this that antigen at the surface of the antigenbearing cells or within them is accompanied by immunoglobulin in the form of antigen-antibody complexes. At any one time the germinal centres of the spleen are presumably the result of stimuli provided by a number of antigens from different sources in the bird's environment. After injection of a specific antigen, the centres that include cells bearing this antigen will form a varying proportion of the total number of centres, all of which show a pattern of cells with fluorescein-labelled anti-chicken-globulin.

The absence of antigen-bearing cells during the first 24-32 hr after injection and the subsequent increase in their numbers along the vessels of the white pulp indicate that this localisation of antigen may depend upon the availability of anti-HSA. The evidence for this hypothesis is as follows: first, the onset of localisation of antigen coincides with, but does not precede, the appearance of anti-HSA-containing plasma cells in the red pulp strands of the spleen, despite a high level of circulating antigen before this time. Secondly, the kinetics of appearance of antigen-antibody complexes in the circulation (fig. 2) coincides in time with the observed localisation of antigen to cells within the white pulp at the 3rd and 4th day. Thirdly, by the use of the immunofluorescence method for detection of chicken immunoglobulin it is possible to identify immunoglobulin within the germinal centres from the 4th day onwards as a pattern identical with that of HSA. Fourthly, no localisation occurs in the bird that is rendered specifically tolerant to HSA.

Germinal centres in the chicken spleen are, in the early stages of their formation, first discernible by the slightly increased cytoplasmic basophilia of their contained lymphoid cells. Later the occurrence of increased numbers of cells showing mitotic figures and the larger size generally of the cells within the 
centre as compared with the cells of the surrounding white pulp, as well as the developing peripheral circular margin of condensed reticulin fibrils, make them increasingly easy to identify. In histological sections of formalin-fixed and waxembedded tissue stained with haematoxylin and eosin or methyl green-pyronin it is not possible to identify clearly the cells that correspond to the antigenbearing cells. The chicken splenic germinal centre does not show a "starry sky " pattern of amoeboid macrophages, such as is seen in the spleen of man. As seen from fig. $7 a$ and $b$ the outline of the fluorescence denoting either antigen or immunoglobulin indicates that the antigen-antibody complex follows the line of the dendritic processes and perikaryon of cells with a morphology that closely resembles that of the microglia. The cells bear no resemblance to amoeboid macrophages, but resemble in outline the argyrophilic macrophages of Marshall (1956).

The above findings, which related to the localisation and persistence of HSA as revealed by the immunofluorescence method, were confirmed and extended by further experiments in which $40 \mu \mathrm{g}$ HSA, which had been heavily labelled with 125I to a level of $25 \mu \mathrm{Ci}$ per $\mu \mathrm{g}$, was injected intravenously into 6-10-wk-old White Leghorn cockerels. This method proved to be considerably more sensitive for the detection of antigen-bearing cells, since tissue sections prepared from birds that had been given an injection of $40 \mu \mathrm{g}$ of HSA failed to show any cell-localised antigen detectable by immunofluorescence.

The same period (up to $36 \mathrm{hr}$ ) was again determined as that during which antigen was not detectable as foci of radioactivity in association with cells or other sites within the chicken spleen, although a heavier, generally distributed or "background" radioactivity was apparent at 16 and $40 \mathrm{hr}$. The first evidence of localisation of antigen was to cells distributed along the branches of the central arteriole of the white pulp (penicillary arterioles) extending from the periphery of the ellipsoids (Schweigger-Seidel sheaths) at the margin with the red pulp up to the point of bifurcation of the central arteriole. A striking feature of the localisation at $88 \mathrm{hr}$ after antigen injection was the occurrence of rings of antigen around the periphery of the ellipsoids (fig. 12b). This occurred as a zone of diffusely increased radioactivity at the periphery of the ellipsoid and extending around it. Within and just outside this zone were dense foci of radioactivity, presumably associated with antigen concentrated on or within individual cells.

As can be seen from fig. $12 b$, the antigen-bearing cells were distributed along the penicillary arterioles in a sharply defined zone around the vessel. No antigen-bearing cells appeared proximal to the point of origin of the penicillary arterioles from the central arteriole (fig. 12b), i.e., no antigen-bearing cells were seen at 40 or $88 \mathrm{hr}$ or at later time-intervals along the extent of the main central arteriole. These appearances suggest that localisation occurs to cells that are either fixed in position along the line of the penicillary arterioles of the white pulp or to cells that are migrating along this line from the periphery of the ellipsoid to the point at which the penicillary arterioles branch off the central arteriole of the white pulp.

Already at $88 \mathrm{hr}$ after antigen injection (fig. $13 a$ and $b$ ) there are collections 
of such antigen-bearing cells within the outlines of the early germinal centres. The data of the autoradiographs show that no antigen-bearing cells are to be found at this time in any of the large fully developed germinal centres (of over $90 \mu \mathrm{m}$ diameter). There is a progressive change in the pattern of localised antigen conforming with a movement of antigen-bearing cells from the zone of the white pulp immediately around the penicillary arterioles and ellipsoids into germinal centres, which are always situated in the angle between the penicillary arterioles close to the point of origin from the main central arteriole (fig. $13 a$ and $b$ ). At 6 days (fig. $14 a$ and $b$ ) all the radio-iodine-labelled antigen is confined within the circular outlines of germinal centres.

This sequence of morphological evidence suggests that antigen-antibody complexes first become detectable extravascularly at the periphery of the ellipsoids (Schweigger-Seidel sheaths). At this site antigen localises to dendritic cells, which subsequently migrate in a zone surrounding the penicillary arterioles to the region of origin of these at the site of division of the central arteriole of the white pulp, where the early germinal centre forms. The appearances suggest that a progressive capture of lymphocytes at the surface of the cytoplasmic extensions of dendritic cells may occur as the latter pass through this " traffic area" of the white pulp of the spleen. The earliest formation of germinal centres occurs at about 3 days, appearing in the autoradiographs as small aggregations of dendritic cells between the diverging penicillary vessels at their origin from the central arteriole (fig. $13 a$ and $b$ ). The early formation of the germinal centre could therefore represent a progressive agglutinative reaction between antigen-bearing dendritic cells and small lymphocytes with antibody at their surface. The demonstration (Sell and Gell, 1965) that antiallotype antisera can induce transformation of rabbit lymphocytes to dividing pyroninophilic cells (large lymphocytes) indicates that available immunoglobulin is present at the lymphocyte surface. In the germinal centre reaction, antigen reacting with homologous antibody at the surface of the small lymphocyte would be the stimulus for the pyroninophilic transformation and subsequent mitotic division that is seen in the early germinal (or lymphocytopoietic) centre. This latter would not represent a clone as previously suggested (White, 1958), but would be the product of the subsequent division of the original small number $(20-40)$ of lymphocytes netted by the dendritic cells.

The long persistence of antigen (visible for about 42 days by immunofluorescence) in or on these dendritic cells, which are scattered within the developing germinal centre so as to be surrounded by and closely related to the dividing lymphoid cells, argues a highly significant role for this small fraction of the injected dose of antigen in specifically directing this proliferation. By an agglutinative process like that suggested above, the initially incorporated cells must be immunologically competent cells of a specificity corresponding to that of the injected antigen, and the resultant ball of multiplied lymphocytes probably consists of cells bearing similar specificity. An agglutinative process such as this would also be expected to provide a mechanism for selection of those lymphocytes of the highest avidity at their cell surface. The subsequent proliferation of these selected cells in the germinal centre would provide the means 
for increase of the general avidity of antibody synthesised later in the immunological response or that following a secondary stimulus (Eisen and Siskind, 1964).

The lymphocytes initially included and subsequently multiplying within a germinal centre are immunologically competent. This is demonstrated by the presence in such lymphocytes of specific antibody detectable by the " sandwich " modification of the fluorescent antibody technique (Coons et al., 1955). As can be seen from fig. 9, antibody-containing cells made their appearance from 13 days onward within a proportion of the antigen-containing germinal centres of the white pulp. After a single injection of $10 \mathrm{mg} \mathrm{HSA}$, centres containing such antibody-containing cells could be found up to 42 days later. The appearances varied from centres enclosing a few scattered cells to centres so packed with cells containing specific antibody that $80-90$ per cent. of the total cells of the centre showed fluorescence by the " sandwich" technique (fig. 9). The individual cells showed a fluorescence that outlined the rim of cytoplasm and was often seen as a spot or spots within the nucleus. The ring of cytoplasm thus outlined was usually broader than that of the typical small lymphocyte and corresponded more with the configuration of an immature plasma cell. Cells with the morphology of mature plasma cells (Marshalkò type) were not evident. Sections stained with fluorescein-labelled rabbit anti-chickenimmunoglobulin show a similar pattern of staining at this time (French, Wilkinson and White, 1969).

The late antibody-containing cells of the germinal centre clearly differ morphologically from the dendritic cells. Whether stained by fluorescent labelled rabbit anti-chicken-immunoglobulin or stained by the "sandwich" technique for specific antibody the dendritic cells present a finely granular pattern of fluorescence shown as a narrow rim at or near the cell surface of the perikaryon and extending along dendritic cytoplasmic processes. Individual fluorescent cells are separated from one another by intervening non-fluorescent cells and are distributed uniformly and symmetrically over the whole area of the germinal centre except for a narrow band at the periphery (fig. 10).

The number or proportion of centres that include late antibody-containing cells is small, so that in a given section perhaps only one or two of 20 antigencontaining centres would be likely to contain antibody. Centres containing specific antibody appeared, sometimes as late as 45 days at least, after a single dose of HSA. A possible explanation for these findings is that for a long part of the proliferative life of a germinal centre the cells do not contain antibody demonstrable by immunofluorescence. Only as the proliferative activity of the cells decreases would the antibody content rise to a demonstrable level.

\section{SUMMARY}

Chickens given an intravenous injection of human serum albumin (HSA) produced a rapid rise of antibody to a peak at 8-9 days, followed by a rapid decline. Plasma cells containing anti-HSA appeared in the spleen at $24 \mathrm{hr}$ after injection. Evidence is presented that early produced antibody causes the localisation of antigen (HSA), presumably as complexes, to cells in the 
white pulp of the spleen at the periphery of ellipsoids (Schweigger-Seidel sheaths) by 24-32 hr. Inspection of a series of tissue sections shows that antigen-bearing cells appear to migrate through the white pulp and subsequently to appear ( $88 \mathrm{hr}-6$ days) as dendritic cells within germinal centres, which originated in the angle between the diverging penicillary arterioles at their point of origin from the central arteriole of the white pulp. A hypothesis is advanced that accounts for the formation of germinal centres by a process of progressive capture and aggregation of lymphocytes at the surface of antigen-bearing dendritic cells. This process is discussed in relation to the progressive increase of avidity in antibody synthesised later in the immunological response or after a secondary stimulus.

It is a pleasure to acknowledge the excellent technical assistance of Mr Murdo Scott.

One of us (V. I. F.) was wholly supported in this work by a research grant from the Scottish Hospitals Endowment Research Trust.

\section{REFERENCES}

Ada, G. L., Nossal, G. J. V., AND Pye, J. 1964. Austral. J. Exp. Biol. Med. Sci., 42, 295. Campbell, D. H., Garvey, June S., 1964. Methods in immunology, New York, Cremer, Natalie E., and Sussdorf, D. $M$.

Coons, A. H., Creech, H. J., Jones, R. N., 1942. J. Immun., 45, 159. AND BERLINER, E.

CoOns, A. H., AND Kaplan, M. H. . 1950. J. Exp. Med., 91, 1.

CoONS, A. H., Leduc, ElizabeTh H., AND 1955. I Ibid., 102, 49. CONNOLLy, JEANNE M.

CoONS, A. H., Leduc, Elizabeth H., AND 1951. Ibid., 93, 173. KAPLAN, M. H.

EISEN, H. N., AND Siskind, G. W.. . 1964. Biochemistry, 3, 996.

FARR, R. S. . . . . . . 1958. J. Infect. Dis., 103, 239.

French, Valentine I., Wilkinson, P. C., 1969. Lymphatic tissue and germinal centers AND WHITE, R. G.

in immune response, ed. by L. FioreDonati and M. G. Hanna, New York, p. 211.

Hunter, W. M., ANd Greenwood, F. C. 1962. Nature, Lond., 194, 495.

Kabat, E. A., AND MAYeR, M. M. 1961. Experimental immunochemistry, 2nd ed., Springfield, Ill., pp. 71-73.

McDevitt, H. O., Askonas, Brigitte A., 1966. Immunology, 11, 337. HUMPHREY, J. H., SCHECHTER, I., AND SEla, M. MARShall, A. H. E. - . - 1956. An outline of the cytology and pathology
of the reticular tissue, Edinburgh, pp. 23 et seqq.

Nossal, G. J. V., Ada, G. L., And Austin, 1964. Austral. J. Exp. Biol. Med. Sci., 42, 311. CAROLINE M.

Sell, S., ANd Gell, P. G. H. 1965. J. Exp. Med., 122, 423.

WHITE, R. G.

1963. Ciba Fdn Study Grps, 16, 6. 